\author{
JACEK KACZOR \\ ORCID: 0000-0002-8609-5113 \\ Uniwersytet Wrocławski \\ Katedra Teorii i Filozofii Prawa
}

\title{
KONIEC ERY KODEKSÓW?
}

\begin{abstract}
Abstrakt: Autor stawia pytanie, czy współcześnie jest jeszcze miejsce na kodeksy w takiej formie, w jakiej były one tworzone w XIX wieku. Przede wszystkim zmieniły się warunki, w jakich powstawały ówczesne kodeksy, oraz postulaty wobec nich stawiane. Nie oczekuje się już obecnie, że akty te będą całkowicie i wyłącznie regulować daną dziedzinę życia społecznego. Nasiliło się zjawisko dekodyfikacji, polegające na regulowaniu materii właściwych kodeksom w innych ustawach, co rodzi problemy na tle ich wzajemnych relacji. Utrudnieniem dla procesu kodyfikacji jest także brak współpracy pomiędzy nauką prawa i sądami, które do tej pory wspólnie wypracowywały rozwiązania, wpisywane następnie do treści kodeksów. Zdaniem autora kodeksy mogą jednak nadal odgrywać ważną rolę i pełnić funkcję w pewnej mierze symboliczną. Najważniejszym zadaniem kodeksów jest bowiem tworzenie aksjologicznych podstaw danej dziedziny prawa, przede wszystkim formułowanie katalogu zasad decydujących o jej autonomii.
\end{abstract}

Słowa kluczowe: kodeks, kodyfikacja, dekodyfikacja, gałąź prawa, tworzenie prawa

Obserwacja polskiej (i nie tylko) praktyki legislacyjnej pokazuje, jak bardzo zatraciło swą aktualność sformułowane przez Jeremy’ego Benthama credo dziewiętnastowiecznych kodyfikatorów: „Co nie jest w kodeksie, nie może być prawem"1. Maksymę tę odczytuję na dwa sposoby: jako przekonanie ogólniejszej natury — o konieczności porządkowania prawa w formie kodeksów — oraz jako bardziej szczegółowy wymóg zupełności kodeksów. Wprawdzie oba te postulaty już u swego zarania obarczone były nadmiernym optymizmem, jednak wyznaczały pewien ideał, któremu powinny być podporządkowane zabiegi kodyfikacyjne. W niniejszym artykule chciałbym zebrać i rozważyć wątpliwości co do możliwości systematyzacji prawa w formie kodeksu. Jak się bowiem wydaje, obecne czasy nie sprzyjają tworzeniu tego typu aktów prawnych.

${ }^{1}$ The Works of Jeremy Bentham, vol. 5. Scotch Reform, Real Property, Codification Petitions [1843], http://oll.libertyfund.org/titles/bentham-the-works-of-jeremy-bentham-vol-5-scotch-reformreal-property-codification-petitions (dostęp: 16.05.2016). 
Dziewiętnastowieczne kodyfikacje były wytworem swojej epoki - efektem oświeceniowego projektu modernizacji świata. Jednym z jego elementów było zaprowadzenie nowego porządku społecznego. $Z$ tej perspektywy kodyfikacja prawa jawiła się wręcz jako zabieg oczywisty i konieczny ${ }^{2}$. Kodyfikacje były w tym kontekście przejawem zarówno wręcz obsesyjnej, nowoczesnej potrzeby porządkowania świata za pomocą ostrych narzędzi naukowych, jak i regulacji w imię „tworzenia warunków” racjonalności ${ }^{3}$. Pamiętać bowiem trzeba, że warunki poprzedzające program kodyfikacyjny były skrajnie odległe od racjonalistycznego ideału pewności i przewidywalności. Ówczesne prawo, zamiast stanowić element utrwalający struktury społeczne, było czynnikiem destabilizującym. Wielość, niepewność i lokalność „praw” wprowadzała stan dezorientacji i nieprzewidywalności. Prawo wymagało ponadto jednoznacznego oddzielenia od tradycji i religii, z którymi było dotychczas ściśle związane.

Odnośnie do tworzenia zrębów nowej wizji prawa i prawotwórstwa należy również podkreślić rolę ideologii liberalnej. Liberalne podejście do prawa cechuje ambiwalencja. $Z$ jednej strony, widząc w nim najbardziej niebezpieczny instrument ingerencji władzy państwowej we wszystkie te obszary, które liberałowie chcieliby chronić, zawsze życzyli oni sobie jak najmniejszej aktywności państwa w tej dziedzinie. $Z$ drugiej zaś - właśnie za pomocą prawa realizowali własny projekt społeczno-ekonomiczny i wytyczali granice indywidualnej wolności. Mimo ewidentnego napięcia pomiędzy chęcią ograniczenia roli państwa a koniecznością implementacji zasad nowego ładu społecznego liberałowie wierzyli w możliwość osiągnięcia złotego środka. Pewną minimalną liczbę regulacji prawnych uważali za nieodzowną chociażby po to, by wyeliminować z życia społecznego konflikty i chaos, które w takim samym stopniu pomniejszają zakres indywidualnej wolności jak władza absolutna. Godzili się więc na obowiązywanie przepisów ograniczających wolność, jeśli uznawali je za konieczne do zminimalizowania liczby konfliktów pomiędzy swobodnie działającymi jednostkami. Temu celowi lepiej odpowiadało prawo nie tyle nakazujące realizację wzorców pożądanych zachowań, ile zabraniające określonych czynów i pozostawiające całą pozostałą sferę swobodnemu uznaniu podmiotów ${ }^{4}$. Deklarowana przez liberalizm idea regulowania w imię ochrony wolności miała w tym wypadku podwójne znaczenie. Nie da się zignorować faktu, że wyznaczająca granice indywidualnej wolności liberalna zasada krzywdy gwarancje wolności zapewniała przez wymuszanie na jednostkach samoograniczenia się. Skoro ład nowoczesny miał być z założenia spójny i oparty na harmonijnej kooperacji jednostek, to i odpowiednio skorelowany z nim musiał być obraz podmiotu prawa. Milczącym założeniem projektu modernizacji świata było przekonanie o dostępności i podatności tego świata na zabiegi re-

${ }^{2} \mathrm{Na}$ kodyfikację jako narzędzie budowania nowego porządku społecznego wskazuje między innymi K. Sójka-Zielińska, Wielkie kodyfikacje XIX wieku, Warszawa 1973, s. 7-8.

${ }^{3}$ A. Elliott, Współczesna teoria społeczna, przeł. P. Tomanek, Warszawa 2009, s. 294, 296.

${ }^{4}$ J. Hołówka, Etyka w działaniu, Warszawa 2001, s. 378. 
gulujące. Dlatego konieczne wydawało się liberałom wyeliminowanie wszelkich niezależnych od jednostki uwarunkowań ograniczających samodzielność rozumu. W tym nowym ładzie człowiek miał być jednostką zdyscyplinowaną, a jego działania - regularne, przewidywalne i podatne na manipulację. Przesłanką takiego stanowiska było przekonanie, że człowiek jest istotą rozumną i społeczną — jako byt w pełni racjonalny kieruje się uniwersalnymi prawami rozumu, nie stanowiąc zaś całości samowystarczalnej dla swej egzystencji, musi wchodzić w relacje z innymi jednostkami. Dlatego też wyznaczające jednostkową wolność „linie graniczne" mogą też być interpretowane nie jako linie odgraniczania (autonomii), lecz także przylegania i dostosowania do innych jednostek ${ }^{5}$.

Narzędziem, za pomocą którego wprowadzane miały być zmiany konieczne do zaprowadzenia nowego ładu społecznego, była nauka, ze względu na jej zdolność rozpoznawania struktur świata, porządkowania go i wyjaśniania. Rezultatem prowadzonych zabiegów miał być świat uporządkowany i ujednolicony ${ }^{6}$. Taki właśnie charakter miał proces dziewiętnastowiecznych kodyfikacji. Zauważa się, że samo pojęcie kodyfikacji nabrało wówczas nowego znaczenia - o ile bowiem zabieg unifikacji prawa znany był już od dawna, o tyle w dobie oświecenia zyskał szczególny sens ideologiczny, jako narzędzie przemian ustrojowych. Nowoczesny kodeks nie miał być jedynie „zwierciadłem prawa” — sprawozdaniem z zastanych reguł zwyczajowych. Kodyfikacja - jako przejaw formalnej racjonalizacji prawa - miała być narzędziem kreowania nowego ładu społecznego, i to kreacją ex nihilo — radykalnie zrywającą z doświadczeniami przeszłości ${ }^{7}$. Fundamentalnie zmieniło się zatem również założenie co do kompetencji prawodawcy, którego rolą było już nie tylko pozbawione elementów woluntarystycznych spisywanie i porządkowanie istniejącego prawa, lecz aktywna i prospektywnie zorientowana polityka prawa, służąca budowie nowoczesnego porządku społecznego. Wiara w kreacyjną moc kodeksu przybrała przy tym wyraz niemal magiczny ${ }^{8}$, sam zaś kodeks jawił się jako byt totalny i omnipotentny, co oddaje przytoczona na wstępie Benthamowska maksyma. Przede wszystkim jednak istotna w omawianym kontekście była metoda budowania nowych kodeksów, oparta na naturalistycznych założeniach swej epoki. Typowym przykładem realizacji tych założeń był niemiecki Bürgerliches Gesetzbuch (BGB) — wzorcowy wytwór niemieckiej Be-

${ }^{5}$ Z. Bokszański, Indywidualizm a zmiana społeczna. Polacy wobec nowoczesności - raport z badań, Warszawa 2007, s. 39.

${ }^{6}$ S. Richert, Podmiotowość ponowoczesna: wieloznaczność tożsamości czy tożsamość wieloznaczności. Propozycja Zygmunta Baumana, „Folia Philosophica” 23, 2010, s. 106.

${ }^{7}$ L. Górnicki, O pojęciu i znaczeniu wielkich kodeksów cywilnych. W związku z książka Katarzyny Sójki-Zielińskiej , Wielkie Kodyfikacje Cywilne. Historia i wspótczesność”, „Kwartalnik Prawa Prywatnego" 2012, z. 1, s. 63.

${ }^{8}$ K. Sójka-Zielińska, op. cit., s. 8-9; S. Salmonowicz, Od Justyniana do Kodeksu Napoleona. Rozważania nad problematyka i terminologia zbiorów prawnych feudalnej Europy (artykuł recenzyjny), „Czasopismo Prawno-Historyczne” 1969, z. 1, s. 194-195. 
griffsjurisprudenz, oparty na precyzyjnych pojęciach prawniczych i abstrahujący od aktualnej sytuacji społeczno-ekonomicznej.

Kodyfikacje końca XIX i pierwszej połowy XX wieku ukształtowały kanon — w przeważającej mierze aktualnych do dziś — wymagań stawianych nowoczesnym kodeksom. Akty te mają zatem dawać wyraz podstawowym założeniom i wartościom konstytuującym instytucjonalne i aksjologiczne fundamenty danej dziedziny prawa, kształtować siatkę pojęciową tej dziedziny, cechować się przy tym zupełnością i wyłącznością zawartej w nich regulacji oraz stabilnością obowiązywania. Taką charakterystykę kodeksu współcześnie potwierdził także Trybunał Konstytucyjny, stwierdzając, że

kodeksom przysługuje szczególne miejsce w systemie prawa ustawowego. Istotą kodeksu jest stworzenie koherentnej i — w miarę możliwości — zupełnej oraz trwałej regulacji w danej dziedzinie prawa [...], kodeksy przygotowywane i uchwalane są w odrębnej, bardziej złożonej procedurze niż „zwyczajne” ustawy, istotą kodeksu jest dokonanie kodyfikacji danej gałęzi prawa. Dlatego terminy i pojęcia używane przez kodeksy traktuje się jako wzorcowe i domniemuje się, iż inne ustawy nadają im takie samo znaczenie. Jest niesporne, że zarówno aksjologia, jak i technika tworzenia prawa traktuje kodeksy w sposób szczególny9.

Do funkcji kodeksów jako „aksjologicznych konstytucji” dziedziny prawa odniosę się jeszcze w końcowej części tego artykułu. Na tym etapie należy natomiast wskazać, że ze względu na swą funkcję integrującą i stabilizującą w obrębie danej gałęzi prawa kodeksy powinny przede wszystkim formułować katalog jej podstawowych zasad ${ }^{10}$.

Postulat zupełności kodeksów, zakładający regulowanie przez nie całości stosunków prawnych zaliczanych do danej dziedziny prawa, był nierealizowalny już w warunkach rozwiniętych stosunków społecznych doby wielkich kodyfikacji, a tym bardziej jest niemożliwy do osiągnięcia współcześnie ${ }^{11}$. Wyprzedzając nieco wnioski, chciałbym w tym miejscu jedynie zasugerować, że zupełność kodeksów można dzisiaj odnosić chyba co najwyżej do wskazanej wcześniej ich funkcji integrującej określoną dziedzinę prawa, i to głównie pod względem jej spójności aksjologicznej. Zatem od przyszłych kodeksów można by wymagać bardziej wyraźnego niż obecnie artykułowania wartości uznawanych za podstawowe dla danej dziedziny.

Co interesujące, mimo że postulat zupełności kodeksów od swego zarania obarczony był grzechem naiwności, to jednak takie oczekiwania wobec aktów pretendujących do miana kodeksów są podnoszone do dziś, o czym najlepiej świad-

${ }_{9}^{9}$ Orzeczenie Trybunału Konstytucyjnego z dnia 18 października 1994 roku, sygn. K 2/94, OTK ZU nr 2/1994, poz. 36.

${ }^{10}$ M. Kępiński, M. Seweryński, A. Zieliński, Rola kodyfikacji na przykładzie prawa prywatnego w procesie legislacyjnym, „Przegląd Legislacyjny” 2006, nr 1 (53), s. 95; G. Wierczyński, Redagowanie i ogłaszanie aktów normatywnych, Warszawa 2016, s. 149.

${ }^{11}$ O różnych sposobach rozumienia zupełności pisze M. Janiszewska, Postulaty kodyfikacyjne wczoraj i dziś, [w:] Prawo wobec wyzwań wspótczesności, t. 2, red. P. Wiliński, Poznań 2005, s. 99. 
czy regulacja zawarta w $§ 19$ pkt 2 ,Zasad techniki prawodawczej"12. Te same „Zasady techniki prawodawczej” w innym przepisie (§ 39 ust. 2) odwołują się do jeszcze jednego idealistycznego postulatu stawianego kodeksom, a mianowicie ich wyłączności. W tym znaczeniu kodeks miałby być jedynym aktem prawnym regulującym daną dziedzinę spraw. Tylko na marginesie zauważyć można, że przy takim znaczeniu zakresy obu używanych w powołanych przepisach orzeczników („wyczerpujący” i „wyłączny”) nie są logicznie rozłączne — skoro kodeks ma wyczerpująco regulować określoną dziedzinę spraw, to w konsekwencji musiałby być jedynym (,wyłącznym”) aktem tę dziedzinę regulującym.

Pożądaną cechą każdego aktu normatywnego jest jego stabilność. Wprawdzie absolutna niepodatność na zmiany jest cechą nieosiągalną nawet w wypadku ustaw zasadniczych, jednak ze względu na fundamentalne, ,quasi-konstytycyjne” dla danej gałęzi prawa, znaczenie kodeksów powinny one być nowelizowane możliwie rzadko i tylko ze względu na istotne powody ${ }^{13}$. Na szczególne zagrożenie dla funkcji kodeksów zwrócił uwagę w powoływanym już wcześniej orzeczeniu Trybunał Konstytucyjny, podkreślając, że

zasady prawidłowej legislacji wymagają więc, by ustawodawca nader rozważnie podejmował nowelizację kodeksów, a w każdym razie, by powstrzymywał się od nowelizowania ich drogą pośrednią, gdy pozornie niezmieniony tekst kodeksu zostaje wydrążony z treści postanowieniami ustaw szczegółowych. Jest to szczególnie ważne, gdy nowelizacja ma dotyczyć kodeksowych unormowań o charakterze zasadniczym, przesądzających samą istotę poszczególnych instytucji danej gałęzi prawa.

Opisana sytuacja należy w moim przekonaniu do jednej z najgroźniejszych w kontekście funkcji pełnionych przez kodeksy, albowiem pozbawianie kodeksu jego konstytutywnej (w obrębie gałęzi prawa) roli dokonuje się w takim wypadku w sposób zakamuflowany, ukryty przez ustanowienie bądź nowelizację jakiejś ustawy szczegółowej. Dopiero egzegeza obu aktów prawnych może doprowadzić do wniosku, że wprowadzenie bądź zmiana owej ustawy szczegółowej istotnie wpłynęła na kształt instytucji uregulowanej w samym kodeksie ${ }^{14}$.

12 Rozporządzenie Prezesa Rady Ministrów z dnia 20 czerwca 2002 roku w sprawie „Zasad techniki prawodawczej" (Dz.U. z 2016 r. poz. 283).

${ }^{13}$ K. Weitz, Czy nowa kodyfikacja postepowania cywilnego?, „Państwo i Prawo” 2007, nr 3, s. 21.

14 Taka sytuacja miała miejsce właśnie w sprawie rozstrzyganej przez Trybunał Konstytucyjny w powoływanym orzeczeniu z dnia 18 października 1994 roku, sygn. K 2/94. Zakwestionowane przez Rzecznika Praw Obywatelskich zostały wówczas przepisy ustawy z dnia 6 marca 1993 roku o zmianie niektórych ustaw regulujących zasady opodatkowania oraz niektórych innych ustaw (Dz.U. Nr 28, poz. 127), zmieniające treść art. 47 ustawy z dnia 19 grudnia 1980 roku o zobowiązaniach podatkowych (Dz.U. Nr 27, poz. 111 z późn. zm.). Zmiany te wprowadzały odpowiedzialność majątkiem własnym komandytariusza i wspólnika spółki z ograniczoną odpowiedzialnością za zobowiązania podatkowe spółki. Zmiany te stały — zdaniem skarżącej — w oczywistej sprzeczności $\mathrm{z}$ istotą wymienionych spółek, co doprowadziło do „zmiany samej istoty polskiego systemu prawa 
Niekiedy od postulatu stabilności kodeksu odróżnia się wymóg jego trwałości, rozumiany jako „założenie, że tworzony jest on jako ustawa na długi czas, a więc również decyzja o jego zastąpieniu nową regulacją musi mieć mocne uzasadnienie i realne podstawy wynikające z potrzeb obrotu prawnego" ${ }^{15}$. Obserwacja dotychczasowej polskiej praktyki legislacyjnej wskazuje, że jest to chyba postulat zrealizowany $\mathrm{w}$ najszerszym stopniu $\mathrm{z}$ wszystkich wymienionych zwłaszcza uwzględniając transformację ustrojową w Polsce, która nie doprowadziła do derogacji wielu kodeksów. Jednak przedwczesne byłoby formułowanie na tej podstawie optymistycznych wniosków, albowiem przykład prób kodyfikacyjnych w obrębie prawa prywatnego pokazuje, że dalsze obowiązywanie starych kodeksów wynika nie tyle z poszanowania prawodawcy ich wartości i aktualności, ile z niemożności opracowania nowych.

Ważne, aczkolwiek niemożliwe do osiągnięcia w stopniu spodziewanym przez oświeceniowych legislatorów, było także inne oczekiwanie, nakierowane na osiągnięcie ideału ius certum, a mianowicie postulat pewności i jasności prawa. Pełna zrozumiałość przepisów miała odebrać prawnikom władzę nad prawem i przekazać je w ten sposób do dyspozycji zwykłych ludzi ${ }^{16}$. Obecnie wymóg ten, choć nadal jest stawiany każdemu tekstowi prawnemu, nie jest już absolutyzowany. Współcześni prawnicy mają (lub przynajmniej powinni mieć) świadomość uwarunkowań dotyczących redagowania tekstów prawnych w języku opierającym się w głównej mierze na języku naturalnym oraz konieczności pogodzenia przez prawodawcę postulatów jasności (komunikatywności) przepisów prawnych i ich precyzji.

Nieformalnym i zupełnie marginalnym ze stricte prawniczego punktu widzenia zapatrywaniem towarzyszącym tworzeniu kodeksów jest przekonanie o ich sprawczej mocy ${ }^{17}$. Naiwność oświeceniowego (lecz także współczesnego) sposobu myślenia o tworzeniu prawa przejawia się w wierze, że samo ustanowienie przepisu prawnego bezwzględnie zmieni rzeczywistość pozaprawną, do której się on odnosi. Taki magiczno-życzeniowy sposób myślenia o działalności prawodawczej prowadzi w rezultacie do nadprodukcji prawa, które — pozbawione wsparcia w postaci realnych działań — pozostaje nieefektywne.

Ponieważ charakteryzując we wstępie tego artykułu warunki towarzyszące tworzeniu pierwszych nowoczesnych kodeksów, wskazałem na istotne znaczenie szeroko rozumianego otoczenia ideologicznego okresu wielkich kodyfikacji, należy również zarysować klimat intelektualny towarzyszący współczesnym zabiegom legislacyjnym. Choć nie podejmę się w ograniczonych ramach tego

spółek handlowych i de facto wyeliminowało z systemu prawa (handlowego) dwa rodzaje spółek w ich pierwotnej konstrukcji”.

15 Tak K. Weitz, op. cit., s. 21.

${ }^{16}$ K. Sójka-Zielińska, Drogi i bezdroża prawa. Szkice z dziejów kultury prawnej Europy, Wrocław 2000, s. 50.

${ }^{17}$ M. Janiszewska, op. cit., s. 101. 
artykułu kwalifikacji obecnych czasów w kategoriach konkretnego prądu myślowego, tym bardziej że nie jest to jeszcze okres w pełni ukonstytuowany, to jednak możliwe jest wskazanie pewnych wyraźnie zauważalnych tendencji, które wywierają przynajmniej pośredni wpływ na działalność prawodawcy. Przede wszystkim obecnie nie mają już takiej siły oddziaływania pojęcia jedności, ładu czy koherencji. W przeciwieństwie do chętnie operującej pojęciami „całości”, „ogółu” czy „systemu” refleksji modernistycznej myśl współczesna akcentuje raczej znaczenie różnicy i różnorodności ${ }^{18}$. Do tego świat współczesny oparty jest na tymczasowości ${ }^{19}$. Pojawiło się pojęcie czasu punktowego, charakteryzującego się niespójnością i przyczynowym następstwem sytuacji. Miejsce sekwencyjności zajęła epizodyczność, historia zaś traktowana jest jako zespół mniej lub bardziej przypadkowych zdarzeń, niepołączonych żadnymi relacjami przyczynowo-skutkowymi. Kwestionuje się ideę „teleosu” (celowości), możliwej jedynie przy założeniu liniowości czasu ${ }^{20}$. W celu opisu warunków życia jednostki stworzono nawet specjalne określenie - nowist culture (kultura terazistyczna). Wyróżniają ją nieustanna presja, pośpiech i brak czasu na zastanowienie. Premiowane są natomiast szybkość i niezastanawianie się przed podjęciem decyzji ${ }^{21}$.

Opisywana wcześniej liberalna koncepcja podmiotu zakładała co najmniej jego potencjalną zdolność do racjonalnego działania i swoiste zuniformizowanie, dzięki czemu mógł on być traktowany jako stała w modernistycznych strategiach. Jak zostało już wskazane, planowanie było nieodzownym elementem projektu modernizacji świata, wymagającym posługiwania się możliwie największą ilością dających się przewidzieć danych. To z kolei opierało się na założeniu, że istnieją pewne wspólnie podzielane przez wszystkich ludzi właściwości, pozwalające przewidywać ich zachowania. Współcześnie szacunek dla różnorodności i odmienności każdej jednostki łączy się z niechęcią do totalności, kryjącej się za próbami przykładania do wszystkich ludzi jednej, z góry narzuconej miary. To samo przekonanie uzasadnia również sprzeciw wobec prób modelowania całych społeczeństw podług jakiejś wyidealizowanej „natury ludzkiej”, która ma koniecznie determinować dany układ stosunków międzyludzkich ${ }^{22}$.

Mogłoby się wydawać, że prawo, ze względu na przynależność do porządku techniczno-ekonomicznego (w terminologii D. Bella) ${ }^{23}$, jest względnie odporne na zjawiska, które na początku dotknęły kulturę. Jednak taka diagnoza byłaby

18 Por. J.F. Lyotard, Kondycja ponowoczesna. Raport o stanie wiedzy, przeł. M. Kowalska, J. Migasiński, Warszawa 1997, s. 20.

19 J. Rifkin, Koniec pracy. Schyłek sity roboczej na świecie i początek ery postrynkowej, przeł.

E. Kania, Wrocław 2003, s. 8-9, 12.

${ }^{20}$ Z. Bauman, Konsumowanie życia, przeł. M. Wyrwas-Wiśniewska, Kraków 2009, s. 40-41.

${ }^{21}$ Ibidem, s. 43-44.

${ }^{22}$ W. Kamińska, Ontologiczne i antropologiczne założenia postmodernizmu, „Słupskie Studia Filozoficzne" 2001, nr 3, s. 59.

${ }^{23}$ D. Bell, Kulturowe sprzeczności kapitalizmu, przeł. S. Amsterdamski, Warszawa 1994, s. $45-46$. 
myląca. Również w jego obrębie zachodzą analogiczne do innych obszarów życia społecznego zjawiska, świadczące o kryzysie jego modernistycznych podstaw. Jednym z warunków efektywnego przeprowadzenia zabiegów kodyfikacyjnych było zarówno ukształtowanie się stabilnego systemu wartości, którym kodeks miał dawać wyraz w postaci katalogu zasad prawa, jak i ustabilizowana sytuacja polityczna, gospodarcza i społeczna ${ }^{24}$. Współczesność cechują dynamicznie zmieniające się uwarunkowania polityczne, trudne do przewidzenia kierunki przemian społecznych i niepewność gospodarcza, dodatkowo potęgowane galopującym postępem technicznym. Wszystkie te cechy są zaprzeczeniem optymalnych warunków tworzenia kodeksów. Przypadłościami współczesnego procesu tworzenia prawa są: nakładanie się źródeł prawa, zaprzeczające elementarnemu sensowi pojęcia systemu prawa chaotyczność i niespójność zbioru norm prawnych, niestabilność i zmienność składników tego „systemu”, doraźność i sytuacyjność stanowionych ustaw ${ }^{25}$. Liczba aktów prawnych i zawartych w nich przepisów jest tak duża, że legislatorzy nie są już w stanie ogarnąć całego systemu prawnego. Skutkuje to specjalizacją, która jest wprawdzie w stanie zapewnić merytoryczną poprawność konkretnego aktu, lecz nie zharmonizowanie z pozostałymi aktami.

Szczególne wyzwania problematyce kodyfikacyjnej stawia sygnalizowane już zjawisko multicentryczności. Wyraża się ono w mnogości zarówno źródeł tworzenia prawa, jak i ośrodków jego stosowania. Na polskie regulacje prawne i organy powołane do ich stosowania nakładają się regulacje europejskie i międzynarodowe oraz złożony układ organów orzekających w tym zakresie. Dla problematyki kodyfikacji szczególnym wyzwaniem jest zagadnienie implementacji aktów prawa wspólnotowego. Zauważa się w tym kontekście, że polski prawodawca wybiera zazwyczaj najłatwiejsze, choć najgorsze z punktu widzenia koherencji systemu prawnego rozwiązanie, polegające na niemal dosłownym przełożeniu treści dyrektywy na język polski i wprowadzeniu jej w formie odrębnej ustawy ${ }^{26}$. Taka praktyka jest typowa zwłaszcza dla regulacji z zakresu prawa konsumenckiego. Jednak to rozwiązanie nie tylko staje się źródłem pytań o relację ustaw implementacyjnych do kodeksu, lecz także podważa status kodeksu jako aktu aspirującego do możliwie całościowego uregulowania danej dziedziny spraw. Zwłaszcza regulowanie stosunków prawnych o wyjątkowej aktualności w ustawach pozakodeksowych rodzi podejrzenie, że kodeks staje się wyłącznie archaicznym „pomnikiem prawa”, bieżące zaś problemy rozwiązywane są poza nim. Dlatego zalecanym rozwiązaniem implementacyjnym jest możliwie najszersze włączanie regulacji objętych zakresem dyrektyw do kodeksów. Jest to jednak zabieg niezwykle trudny do przeprowadzenia, gdyż wymagający wieloaspektowego dostosowania treści i języka dyrektyw do rozwiązań kodeksowych. Pomijając przypadki, gdy stopień

\footnotetext{
${ }^{24}$ M. Kępiński, M. Seweryński, A. Zieliński, op. cit., s. 96; K. Weitz, op. cit., s. 21.

${ }^{25}$ E. Łętowska, Prawo w „ptynnej nowoczesności”, „Państwo i Prawo” 2014, nr 3, s. 9.

${ }^{26}$ M. Kępiński, M. Seweryński, A. Zieliński, op. cit., s. 103.
} 
trudności takiej operacji uniemożliwia włączenie treści dyrektyw do kodeksu, w pozostałych sytuacjach należy upatrywać raczej wspomnianej już „doraźności” działania prawodawcy i niechęci do podejmowania dodatkowego wysiłku. Być może jest to spowodowane także oceną zabiegu implementacyjnego jako problemu o przede wszystkim politycznej naturze, w tym sensie, że implementacja prawa wspólnotowego jest postrzegana przez prawodawcę (rozumianego w tym miejscu przede wszystkim jako decydenta politycznego) w kontekście zadania, które musi zostać zrealizowane ze względu na zobowiązania członkowskie, kwestie zaś prawnej („ogólnosystemowej”) poprawności takiego zabiegu nabierają z tej perspektywy drugoplanowanego znaczenia. Boleśnie jest bowiem odczuwana przez prawników konstatacja, że tworzenie prawa jest w głównej mierze aktywnością o charakterze politycznym i dopiero rolą prawników - zarówno przedstawicieli nauki prawa, jak i judykatury — jest uporządkowanie owego wytworu żywiołu politycznego oraz nadanie mu kształtu systemu prawa.

Skoro mowa o nauce prawa i orzecznictwie sądowym, to odnotować należy również zarzuty kierowane $\mathrm{w}$ tę stronę. Nie należą bowiem do odosobnionych opinie, że obecny model zarówno uprawiania dogmatyki prawa, jak i nauczania prawa nie przystaje do potrzeb generowanych przez opisane warunki, w których tworzone jest prawo. W pełni zasadny jest przede wszystkim zarzut koncentrowania się przedstawicieli szczegółowych nauk prawnych na rozwiązywaniu doraźnych problemów, rozważanych ahistorycznie i bezkontekstowo. Nie chodzi przy tym o fasadowe tylko poprzedzanie analiz określonych instytucji czy konstrukcji prawnych „rysem historycznym”, lecz o rzetelne zrekonstruowanie ich zmienności i miejsca $\mathrm{w}$ porządku prawnym ${ }^{27}$. Współczesny model uprawiania dogmatyki prawa określiłbym mianem „stechnicyzowanego” - nastawionego na praktyczną skuteczność i unikającego refleksji wykraczającej poza aktualne tylko potrzeby obrotu prawnego. Szczególnie razi w tym kontekście niechęć do rozważań aksjologicznych, do poszukiwania uzasadnień analizowanych instytucji prawnych w zbiorze wartości konstytuujących fundamenty danej gałęzi prawa. Tymczasem bez takiej refleksji nie sposób podejmować jakichkolwiek zamysłów kodyfikacyjnych. Określenie aksjologicznych podstaw danej dziedziny prawa jest bowiem warunkiem sine qua non każdego projektu kodyfikacyjnego, jeśli tylko ma on zakończyć się stworzeniem aktu wewnętrznie koherentnego. Tymczasem przykład rozważań z obszaru o wyjątkowo rozwiniętych i historycznie głębokich korzeniach aksjologicznych, jakim jest prawo cywilne, pokazuje, że często bazują one na podręcznikowych ustaleniach, ignorujących fakt, że autonomia woli, równość stron czy odpowiedzialność, o której pisano w momencie wyniesienia tych

${ }^{27}$ E. Łętowska, op. cit., s. 13; J. Andrzejewski, Czy nowa kodyfikacja prawa cywilnego jest potrzebna w czasie kryzysu prawa?, „Ruch Prawniczy, Ekonomiczny i Socjologiczny” 2014, nr 1, s. $80-81$. 
wartości do miana podstawowych wyznaczników tej gałęzi prawa, przeszły daleką drogę i wymagają redefinicji.

Analogiczne zarzuty stawia się orzecznictwu sądowemu, które przedkłada szybkość orzekania nad systematyzację własnego dorobku orzeczniczego, rozumianą jako wpisywanie się kolejnych rozstrzygnięć w „system” dotychczasowych orzeczeń. Konsekwencją takiego stanu rzeczy jest orzekanie a casu ad casum $^{28}$. Należy do tego również dodać irytujący sposób uzasadniania orzeczeń, polegający na przedstawianiu przez sąd rozwiązania określonego problemu jako oczywistego i bezalternatywnego, nawet jeśli w ten sposób sąd rozstrzygnął wyjątkowo trudny i wieloaspektowy problem interpretacyjny. W szczególności od sądów najwyższych instancji, które nie muszą się już obawiać kontroli swoich rozstrzygnięć, można by oczekiwać, że ich wyroki będą miały dyskursywny charakter. Brak interakcji między orzecznictwem sądowym a dorobkiem nauki prawa uniemożliwia realizację najbardziej pożądanego modelu wypracowywania propozycji kodyfikacyjnych, polegającego na uprzednim weryfikowaniu określonych rozwiązań w dyskursie doktryny i judykatury, a następnie ich wprowadzaniu do systemu prawnego na drodze rozstrzygnięć legislacyjnych. Normą za to staje się rozwiązanie przeciwne, gdy prawodawca najpierw wprowadza określone regulacje, a dopiero negatywna reakcja na nie nauki prawa i orzecznictwa sądowego zmusza go do ich zmiany ${ }^{29}$.

Czynnikiem uzasadniającym postawienie znaku zapytania na końcu tytułu artykułu nie są bynajmniej zgłaszane gdzieniegdzie nawoływania do tworzenia nowych kodeksów (na przykład zabezpieczeń społecznych czy prawa ochrony środowiska) $)^{30}$. Są to bowiem zazwyczaj głosy przedstawicieli dyscyplin „dojrzewających” do stanu samodzielności, uzasadniającego — w przekonaniu pretendentów - posiadanie własnego kodeksu. Jest to więc bardziej przejaw ambicji prawników reprezentujących daną dyscyplinę niż dowód realnej potrzeby kodyfikacji.

Co więc w warunkach postępującej dekodyfikacji i niesprzyjającego tworzeniu nowych kodeksów klimatu intelektualnego uzasadnia wyrażoną w tytule wątpliwość odnośnie do perspektyw kodyfikacji? W moim przekonaniu takim optymistycznym elementem jest fenomen kodeksów jako aktów pełniących w prawie funkcję w dużej mierze symboliczną. Konstytuując fundamenty aksjologiczne danej gałęzi prawa, kodeksy odgrywają rolę, jaką w socjologii przypisuje się mitom, rozumianym jako zespoły twierdzeń, których podstawowa funkcja polega na wyjaśnianiu świata i upraszczaniu jego złożoności, podtrzymywaniu bytu określonych instytucji i praktyk poprzez wytwarzanie przekonania o ich konieczności bądź oczywistości,

${ }^{28}$ E. Łętowska, op. cit., s. 11; J. Andrzejewski, op. cit., s. 82-83.

${ }^{29}$ Por. J. Andrzejewski, op. cit., s. 83-85.

30 Por. A. Szybkie, Czy w Polsce potrzebny jest kodeks zabezpieczenia społecznego?, „Ubezpieczenia Społeczne" 2013, nr 3, s. 23-24; P. Korzeniowski, O potrzebie kodyfikacji prawa ochrony środowiska, [w:] Prawne aspekty gospodarowania zasobami środowiska, t. 2. Oddziatywanie na zasoby środowiska, red. B. Rakoczy, M. Szalewska, K. Karpus, Toruń 2014, s. 27-40. 
dostarczaniu wzorców zachowań i motywowaniu do ich podejmowania ${ }^{31}$. Kodeksy, zajmując centralne miejsca $\mathrm{w}$ danej gałęzi prawa, odgrywają istotną rolę integracyjną, spajając tę gałąź wokół określonych wartości. Doskonałym przykładem takiego sposobu funkcjonowania kodeksów jest obowiązywanie kodeksu cywilnego w okresie gospodarki centralnie planowanej. Ówczesnemu prawodawcy również tym razem nie udało się zbudować kodeksu ex nihilo — zrywającego z aksjologicznymi korzeniami prawa prywatnego. Dlatego pomimo niewyrażonej w nim expressis verbis zasady swobody umów była ona nadal rekonstruowana $\mathrm{z}$ różnych przepisów tego kodeksu i uważana za fundament całego prawa cywilnego ${ }^{32}$. Sądzę, że właśnie w tej roli kodeksy utrzymają swój status centralnych aktów w gałęziowym mikrokosmosie poszczególnych dziedzin prawa. Nie oznacza to bynajmniej, że powinny zawierać wyłącznie zestaw zasad prawa i podstawowych definicji. Jest w nich miejsce na uregulowanie wszystkich tradycyjnie ukształtowanych konstrukcji i instytucji prawnych, wpisujących się w aksjologiczny format danego kodeksu. Przy takim założeniu rolą ustaw szczegółowych byłoby normowanie materii niemieszczących się w tych ramach bądź mogących godzić w stabilność regulacji kodeksowych. Takie rozwiązanie oznacza wprawdzie istotne zmniejszenie ambicji towarzyszących zabiegom kodyfikacyjnym, ale — jak starałem się to wykazać większość nowoczesnych postulatów stawianych opracowywaniu kodeksów dawno już zatraciła swój pierwotny, zazwyczaj zbyt idealistyczny, wydźwięk.

\title{
END OF THE ERA OF CODES?
}

\author{
Summary
}

The author of the article asks the question whether there is still space for codes in the form in which they were created in the nineteenth century. The conditions for the creation of codes have changed. Lawyers do not require codes in order to completely regulate a given field of social life. The occurrence of decodification is very strong. Lack of cooperation between legal science and the courts makes it difficult to create new codes. However, in the author's opinion, codes can still play an important and symbolic role. The most important function of codes is to create the axiological foundations of a given branch of law.

Keywords: code, codification, decodification, branch of law, law-making

${ }^{31}$ Obszernego i wszechstronnego przeglądu różnych sposobów pojmowania mitu dostarczają między innymi J. Jabłońska-Bońca, Prawo w kręgu mitów, Gdańsk 1995; M. Woźniak, Doświadczanie historii. Kulturowy i społeczny wymiar mitu rewolucji, Lublin 2003.

32 Z. Radwański, Teoria umów, Warszawa 1977; S. Grzybowski, [w:] System prawa cywilnego. Część ogólna, t. 1, red. S. Grzybowski, Wrocław 1974, s. 475; J. Nowacki, Wolność umów a uzasadnienie analogii, „Państwo i Prawo” 1966, nr 11, s. 743. 


\section{BIBLIOGRAFIA}

Andrzejewski J., Czy nowa kodyfikacja prawa cywilnego jest potrzebna w czasie kryzysu prawa?, „Ruch Prawniczy, Ekonomiczny i Socjologiczny” 2014, nr 1.

Bauman Z., Konsumowanie życia, przeł. M. Wyrwas-Wiśniewska, Kraków 2009.

Bell D., Kulturowe sprzeczności kapitalizmu, przeł. S. Amsterdamski, Warszawa 1994.

Bokszański Z., Indywidualizm a zmiana społeczna. Polacy wobec nowoczesności - raport z badań, Warszawa 2007.

Elliott A., Współczesna teoria społeczna, przeł. P. Tomanek, Warszawa 2009.

Górnicki L., O pojęciu i znaczeniu wielkich kodeksów cywilnych. W zwiazku z książka Katarzyny Sójki-Zielińnkiej ,,Wielkie Kodyfikacje Cywilne. Historia i współczesność”, „Kwartalnik Prawa Prywatnego" 2012, z. 1.

Hołówka J., Etyka w działaniu, Warszawa 2001.

Janiszewska M., Postulaty kodyfikacyjne wczoraj i dziś, [w:] Prawo wobec wyzwań wspótczesności, t. 2, red. P. Wiliński, Poznań 2005.

Kamińska W., Ontologiczne i antropologiczne zatożenia postmodernizmu, „Słupskie Studia Filozoficzne" 2001, nr 3.

Korzeniowski P., O potrzebie kodyfikacji prawa ochrony środowiska, [w:] Prawne aspekty gospodarowania zasobami środowiska, t. 2. Oddziaływanie na zasoby środowiska, red. B. Rakoczy, M. Szalewska, K. Karpus, Toruń 2014.

Lyotard J.-F., Kondycja ponowoczesna. Raport o stanie wiedzy, przeł. M. Kowalska, J. Migasiński, Warszawa 1997.

Łętowska E., Prawo w „płynnej nowoczesności”, „Państwo i Prawo” 2014, nr 3.

Kępiński M., Seweryński M., Zieliński A., Rola kodyfikacji na przykładzie prawa prywatnego w procesie legislacyjnym, „Przegląd Legislacyjny” 2006, nr 1 (53).

Nowacki J., Wolność umów a uzasadnienie analogii, „Państwo i Prawo” 1966, nr 11.

Orzeczenie Trybunału Konstytucyjnego z dnia 18 października 1994 roku, sygn. K 2/94, OTK ZU nr 2/1994, poz. 36 .

Radwański Z., Teoria umów, Warszawa 1977.

Richert S., Podmiotowość ponowoczesna: wieloznaczność tożsamości czy tożsamość wieloznaczności. Propozycja Zygmunta Baumana, „Folia Philosophica” 23, 2010.

Rifkin J., Koniec pracy. Schyłek sity roboczej na świecie i początek ery postrynkowej, przeł. E. Kania, Wrocław 2003.

Rozporządzenie Prezesa Rady Ministrów z dnia 20 czerwca 2002 roku w sprawie „Zasad techniki prawodawczej" (Dz.U. z 2016 r. poz. 283).

Salmonowicz S., Od Justyniana do Kodeksu Napoleona. Rozważania nad problematyka i terminologia zbiorów prawnych feudalnej Europy (artykuł recenzyjny), „Czasopismo Prawno-Historyczne" 1969, z. 1.

Sójka-Zielińska K., Drogi i bezdroża prawa. Szkice z dziejów kultury prawnej Europy, Wrocław 2000. Sójka-Zielińska K., Wielkie kodyfikacje XIX wieku, Warszawa 1973.

System prawa cywilnego. Część ogólna, t. 1, red. S. Grzybowski, Wrocław 1974.

Szybkie A., Czy w Polsce potrzebny jest kodeks zabezpieczenia społecznego?, „Ubezpieczenia Społeczne" 2013, nr 3.

Weitz K., Czy nowa kodyfikacja postępowania cywilnego?, „Państwo i Prawo” 2007, nr 3.

Wierczyński G., Redagowanie i ogłaszanie aktów normatywnych, Warszawa 2016. 